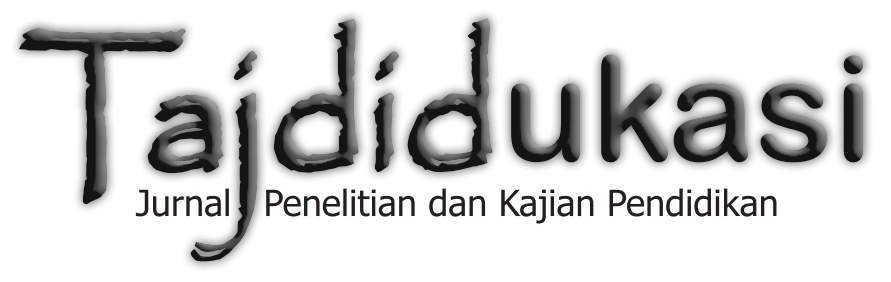




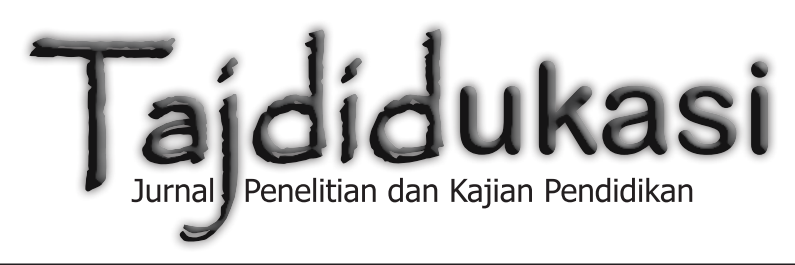

Volume VIII, No. 2, Juli 2018

ISSN: 1979-6943

Tajdidukasi: Jurnal Penelitian dan Kajian Pendidikan merupakan jurnal Penelitian dan Kajian Pendidikan yang berisi Penelitian Tindakan Kelas (PTK) dan Penelitian Tindakan Sekolah (PTS) serta Kajian Pendidikan interdisipliner di Perguruan Tinggi yang diterbitkan Majelis Pendidikan Dasar dan Menengah Pimpinan Wilayah Muhammadiyah Daerah Istimewa Yogyakarta. Artikel hasil PTK dan PTS serta kajian pemikiran pendidikan ditulis oleh para Guru dan Kepala Sekolah serta Dosen dalam mengujicobakan metode dan strategi pembelajaran untuk meningkatkan kualitas pendidikan baik SD/MI, SMP/MTs dan SMA/MA/SMK serta Perguruan Tinggi. Artikel PTK dan PTS fokus pada mata pelajaran di sekolah/madrasah, seperti Ilmu Pengetahuan Alam (IPA), Imu Pengetahuan Sosial (IPS), Matematika, Fisika, Kimia, bahkan teknik, seperti Teknik Mesin, Elektro, Informatika dan lain sebagainya. Sementara itu, artikel Kajian Pendidikan merupakan penelitian interdisipliner dan multidisipliner yang dilakukan Dosen di Perguruan Tinggi terhadap khasanah keIslaman.

Tajdidukasi: Jurnal Penelitian dan Kajian Pendidikan adalah jurnal terbuka yang versi softfile-nya bisa dibaca dan diakses secara gratis, sementara versi print out/ hardcopy dapat diperoleh dengan menghubungi distributor di alamat serial tajdidukasi.ac.id. Sof-file keseluruhan artikel yang diterbitkan dapat diakses melalui Tajdidukasi Open Access Juornal di www.dikdasmenpwmdiy.or.id

Pimpinan Editor
Suyadi, Universitas Ahmad Dahlan (UAD) Yogyakarta, Indonesia

Anggota Editor

Arif Budi Raharjo, Universitas Muhammadiyah Yogyakarta (UMY), Indonesia

Achmad Muhammad, UIN Sunan Kalijaga Yogyakarta, Indonesia

Hendro Widodo, Universitas Ahmad Dahlan (UAD) Yogyakarta

Mundzirin Yusuf, UIN Sunan Kalijaga Yogyakarta, Indonesia

Sumedi, UIN Sunan Kalijaga Yogyakarta, Indonesia

Sukamto, Universitas Muhammadiyah Yogyakarta (UMY), Indonesia

Sumarsono, UIN Sunan Kalijaga Yogyakarta Indonesia

Sarjilah (Lembaga Penjaminan Mutu Pendidikan) Yogyakarta

Fathur Rahman, M.Si., Universitas Negeri Yogyakarta (UNY) Indonesia

\section{Editor Pelaksana}

Suryanto, Universitas Muhammadiyah Yogyakarta (UMY), Indonesia

Suyatno, Universitas Ahmad Dahlan (UAD) Yogyakarta

Farid Setiawan, Universitas Ahmad Dahlan (UAD) Yogyakarta

Alamat Redaksi:

Kantor Majelis Pendidikan Dasar dan Menengah Pimpinan

Wilayah Muhammadiyah D.I. Yogyakarta

J1. Gedongkuning No. 130B Yogyakarta

Kode Pos : 55171

Telephone : (0274) 377078

Facsimile : (0274) 371718

Website : www.dikdasmenpwmdiy.or.id

E-Mail : tajdidukasi@dikdasmenpwmdiy.or.id 


\title{
PENINGKATAN MINAT BERWIRAUSAHA SISWA MELALUI PEMBELAJARAN TEAM GAME TOURNAMENT (TGT)
}

\author{
Yusron Ardi Darmawan \\ SMA Muhammadiyah 1 Yogyakarta \\ E-mail : yusronardi@yahoo.co.id
}

\begin{abstract}
Abstrak
Penelitian ini berjudul: "Peningkatan Minat Berwirausaha Siswa Melalui Pembelajaran Team Game Tournament (TGT)". Penelitian ini bertujuan untuk mengetahui pengaruh penerapan model Team Game Tournament dalam pembelajaran Prakarya dan Kewirausahaan untuk peningkatan minat berwirausaha siswa. Penelitian ini menggunakan metode penelitian tindakan (action research) yang menggambarkan bagaimana suatu metode dan media diterapkan dalam pembelajaran dan mendeskripsikan capaian secara maksimal. Prosedur tindakan dilakukan dalam dua siklus, setiap siklus dilakukan dalam satu kali pertemuan. Adapun langkah-langkahnya adalah: Merencanakan, melaksanakan, mengobservasi, dan merefleksi tindakan dari siklus yang telah berlangsung. Hasil penelitiannya adalah rata-rata nilai siswa mengalami peningkatan dari siklus pertama sebesar 82,29 , menjadi 85,52 pada siklus kedua. Peningkatan ini didukung dengan hasil angket bahwa pada siklus kedua terjadi peningkatan jumlah prosentase siswa yang menyatakan setuju dan sangat setuju terhadap pernyataan positif tentang minat berwirausaha. Artinya, mulai ada peningkatan minat atau ketertarikan untuk berwirausaha siswa kelas XI SMA Muhammadiyah 1 Kota Yogyakarta tahun ajaran 2017 / 2018.
\end{abstract}

Kata Kunci : Team Game Tournament, Pembelajaran, Prakarya dan Kewirausahaan

\section{A. PENDAHULUAN}

Pendidikan adalah kebutuhan pokok manusia oleh karena itu pendidikan wajib dimiliki oleh mereka, dari lahir hingga akhir hayatnya. Seiring berkembangnya zaman, banyak perubahan di dunia pendidikan sebagai upaya peningkatan kualitas pendidikan. Salah satunya adalah model pembelajaran. Saat ini, dalam kurikulum 2013 lebih banyak digunakan model pembelajaran kooperatif. Model pembelajaran kooperatif didasarkan atas falsafah homo homini socius, falsafah ini menekankan bahwa manusia adalah mahluk sosial Sardiman (2001: 27). Maksudnya, manusia hidup saling tergantung. Sedangkan menurut Slavin (2008: 2) model pembelajaran kooperatif merupakan model pembelajaran yang membantu siswa mempelajari isi akademik dan hubungan sosial. Ciri khusus pembelajaran kooperatif mencakup lima unsur yang harus diterapkan, yang meliputi saling ketergantungan positif, tanggung jawab perseorangan, tatap muka, komunikasi 
antar anggota dan evaluasi proses kelompok Sardiman (2001: 30).

Pembelajaran terpusat pada guru sampai saat ini masih menemukan beberapa kelemahan. Kelemahan tersebut dapat dilihat pada saat berlangsungnya proses pembelajaran di kelas, interaksi aktif antara siswa dengan guru atau siswa dengan siswa jarang terjadi. Siswa kurang terampil menjawab pertanyaan atau bertanya tentang konsep yang diajarkan. Siswa kurang bisa bekerja dalam kelompok diskusi dan pemecahan masalah yang diberikan. Mereka cenderung belajar sendiri-sendiri. Pengetahuan yang didapat bukan dibangun sendiri secara bertahap oleh siswa atas dasar pemahaman sendiri. Karena siswa jarang menemukan jawaban atas permasalahan atau konsep yang dipelajari.

Pendidikan Prakarya dan Kewirausahaan merupakan mata pelajaran wajib pada jenjang SMA di kurikulum 2013. Idealnya dengan adanya mata pelajaran ini siswa diri siswa akan tumbuh motivasi dan minat untuk berwirausaha. $\mathrm{H}$ Djaali (2008: 81) menyatakan bahwa minat adalah rasa lebih suka dan rasa ketertarikan pada suatu hal atau aktivitas, tanpa ada yang menyuruh. Sedangkan menurut Winkel (2004: 212), minat dapat diartikan sebagai kecenderungan subyek yang menetap, untuk tertarik pada bidang studi atau pokok bahasan tertentu dan merasa senang mempelajari materi itu. Hasil observasi dan selama mengajar di kelas, peneliti mendapatkan siswa kelas XI Jurusan IPA SMA Muhammadiyah 1 Yogyakarta kesulitan dalam menjawab pertanyaan secara lisan dan tulisan menghubungkan materi yang disampaikan dalam kaitannya dengan kehidupan sehari-hari. Kompetensi inti Prakarya dan Kewirausahaan SMA Kelas XI semester 2 adalah pengolahan bahan pangan. Salah satu materi yang yang dirasa sulit oleh siswa yaitu teori mengenai karekteristik jiwa kewirausahaan, sebagian siswa tidak dapat mengartikan bagaimana sebenarnya karekteristik jiwa wirausaha berkaitan dengan meningkatkan minat berwirausaha setelah mengikuti pembelajaran. Menurut pendapat Agatha Dita Kristsada (2010: 39), Pada hakekatnya minat adalah hubungan sebab akibat dari pengalaman. Menurut Maman S (2006: 43), minat wirausaha adalah gejala psikis untuk memusatkan perhatian dan berbuat sesuatu terhadap wirausaha itu dengan perasaan senang karena membawa manfaat bagi dirinya. Berdasarkan penelitian Ida Yulianti (2013: 18) dinyatakan bahwa minat wirausaha adalah kecenderungan hati dalam diri subjek seseorang untuk tertarik menciptakan suatu usaha yang kemudian mengorganisir, mengatur, menanggung risiko dan mengembangkan usaha yang diciptakannya tersebut. Berdasarkan pengamatan peneliti, sebagian siswa kurang memiliki mimpi yang tinggi, percaya diri (self confidence), pengambil risiko, kepemimpinan, kerja keras, kreatif dan inovatif, suka tantangan dalam dirinya.

Hasil pengamatan menunjukkan bahwa siswa masih belum bisa men- 
ginternalisasi dan menjiwai nilai - nilai yang harus dikuasai dalam pembelajaran kewirausahaan yang nantinya diharapkan akan melahirkan seorang wirausahawan muda. Wirausahawan adalah orang yang melihat adanya peluang kemudian menciptakan sebuah sumber daya dan organisasi untuk memanfaatkan peluang tersebut. Pendapat tersebut dikemukakan oleh $\mathrm{H}$. Buchari Alma (2004: 12) yang menyebutkan bahwa "Entrepreneur is the person who perceives an opportunity and creates an organization to persue it". Menurut Kasmir (2006: 18) dan Sudjana (2004: 131), berpendapat kewirausahaan adalah suatu kemampuan untuk menciptakan kegiatan usaha. Sedangkan Jamal Ma'mur Asmani (2011:21) menyatakan bahwa pada dasarnya kewirausahaan bergerak dari kebutuhan dasar manusia untuk berprestasi. Apabila tidak ada program peningkatan minat, maka akan mengakibatkan merosotnya nilai dan jiwa wirausaha siswa tersebut. Evita Singgih (2006: 88) berpendapat bahwa untuk meningkatkan minat perlu penataan lingkungan fisik maupun lingkungan sosial melalui pembelajaran atau pelatihan. Menurut Maman S (2006: 46) menyatakan bahwa pendidikan kewirausahaan dapat menjadi pendorong pertumbuhan minat kewirausahaan di era modern ini Amir Hamzah Nasution (2003: 47) dan Evita Singgih (2006: 88), mengemukakan ada cara meningkatkan minat salah satunya melalui training. Training adalah sebuah upaya mengingat kembali semangat untuk me- ningkatkan ilmu dan ketrampilan agar semakin baik. Untuk itu, peneliti ingin lebih mendalam lagi dalam menggunakan metode pembelajaran Cooperative ini. Model pembelajaran sekarang ini tidak lagi terpusat pada guru (teacher center), akan tetapi lebih terpusat, melibatkan dan keaktifan siswa (student center) dalam proses pembelajaran. Membuat kelompok kecil agar siswa lebih mandiri dan aktif dalam proses pembelajaran.Model ini disebut juga model pembelajaran Cooperative.

Dalam pembelajaran peneliti menemukan fakta bahwa siswa perlu siswa dibentuk dalam kelompok-kelompok untuk saling membantu dalam memahami materi dan mengerjakan tugas sebagai sebuah kelompok dan dipadu dengan kompetensi antar anggota dalam bentuk kerja kelompok yang menyenangkan. Untuk memperbaiki hal tersebut perlu disusun suatu pendekatan dalam pembelajaran yang lebih komprehensif dan dapat menghubungkan materi teori dengan kenyataan yang ada di lingkungan sekitarnya. Trianto, (2010:45) menyatakan bahwa setiap wirausahawan (entrepreneur) yang sukses memiliki unsur pokok yaitu kemampuan dan ketrampilan. menurut Alma (2003) kemampuan dan ketrampilan ini akan melahirkan karekteristik kewirausahaan yang di kenal dengan 10 D diantanya: Dream, Decisivenes, Doers, Determination, Dedication, Devotion, Details, Destiny, Dollar, Distribute. Atas dasar itulah peneliti mencoba mengembangkan pendekatan 
kooperatif dalam pembelajaran dengan metode Team Game Tournament. Nur \& Wikandari (2000) menjelaskan bahwa Teams games tournament (TGT) telah digunakan dalam berbagai macam mata pelajaran. Salah satu keunggulan teknik ini adalah siswa bekerja kelompok sambil belajar menjiwai suatu konsep atau topik dalam suasana yang menyenangkan sekaligus memberi pengetahuan sebagai gambaran pilihan usaha yang akan ditekuni siswa ketika sudah lulus nantinya. Pernyataan ini sesuai dengan pendapat Slavin (2008: 58), bahwa pengaruh pembelajaran kooperatif terhadap pencapaian belajar siswa dapat meningkatkan persepsi siswa terhadap sesuatu. Penelitian yang dilakukan oleh Budi Wahyono (2013) dalam tesisnya yang berjudul "Pengaruh Pendidikan Kewirausahaan terhadap Niat Berwirausaha Siswa SMK N 1 Pedan Tahun 2013" juga menyatakan bahwa terdapat perbedaan niat berwirausaha yang signifikan antara kelas kewirausahaan dengan praktik dengan kelas kewirausahaan tanpa praktik.

Penggunaan metode tersebut dilakukan melalui penelitian tindakan kelas yang dilaksanakan selama kurang lebih dua bulan. Penelitian tindakan kelas memiliki tujuan untuk mengetahui pengaruh penerapan model Team Game Tournament dalam pembelajaran Prakarya dan Kewirausahaan untuk peningkatan minat berwirausaha siswa. Penelitian tindakan kelas dimaksudkan untuk menemukan model pembelajaran yang aktif dan menyenangkan agar pembelajaran Prakarya dan Kewirausahaan semakin digemari siswa dan menumbuhkan ghirah siswa untuk terjun menjadi seorang pengusaha.

\section{B. METODE PENELITIAN}

Jenis penelitian yang digunakan adalah penelitian tindakan. Penelitian tindakan (action research) dilakukan dalam upaya memecahkan masalah pembelajaran di kelas. Penelitian ini juga termasuk penelitian deskriptif, sebab menggambarkan bagaimana suatu metode dan model pembelajaran diterapkan dan bagaimana hasil yang diinginkan dapat dicapai secara maksimal.Tokoh Penelitian Tindakan adalah Stephen M. Corey. Tokoh ini mempelopori pemanfaatan penelitian tindakan untuk guru, yang kemudian dikenal sebagai Penelitian Tindakan Kelas (Arikunto, 2008: 102).

Desain dalam penelitian tindakan kelas disebut juga pola atau model yang dilaksanakan sebagai langkah konkret merencanakan, melaksanakan, mengobservasi, dan merefleksi tindakan setiap siklus yang telah berlangsung. Subjek penelitian tindakan kelas ini adalah siswa kelas XI SMA Muhammadiyah 1 Yogyakarta Tahun Ajaran 2017/2018. Waktu penelitian dilaksanakan pada semester Genap bulan Februari sampai Maret tahun pelajaran 2017/2018. 


\section{HASIL PENELITIAN DAN PEMBAHASAN}

\section{Diskripsi Siklus Pertama}

Perencanaan. Perencanaan tindakan dilakukan oleh guru. Berdasarkan hasil pengamatan pada pembelajaran sebelumnya dan guru mengidentifikasi masalah yang terjadi. Guru menerapkan model pembelajaran TGT supaya peserta didik tidak bosan, adanya game dan tournament yang membuat pelajaran menjadi menyenangkan, peserta didik lebih mudah memahami materi, guru dan peserta didik berinteraksi secara penuh sehingga peserta didik dan guru bisa sama-sama aktif dan peserta didik memiliki motivasi tinggi untuk belajar, dengan belajar menyenangkan dan adanya kompetisi secara sehat maka peserta didikpun akan bersemangat untuk belajar dan hasil belajar akan meningkat. Setelah itu guru menyiapkan media belajar berupa hand out serta membuat instrumen penelitian berupa lembar observasi, catatan lapangan, soal post test dan lembar penilaian peserta didik. Selain itu juga menyiapkan kamera untuk dokumentasi kegiatan.

Tindakan (Acting) Kegiatan inti pembelajaran pada pertemuan pertama adalah guru menjelaskan kepada peserta didik terkait sistem produksi dan modal yang dibutuhkan terkait pengolahan usaha makanan. Guru melakukan tanya jawab dengan peserta didik terkait pengertian dan penjabaran dari sistem produksi dan modal untuk menumbuhkan perhatian siswa. Kegiatan pembelajaran menekankan pada proses pembelajaran yang bersifat aktif. Kegiatan pembelajaran menggunakan model pembelajaran TGT menekankan pada diskusi kelompok, permainan akademik, dan turnamen. Belajar dalam kelompok (teams), guru membagi peserta didik menjadi lima kelompok yang beranggotakan masing-masing kelompok enam atau tujuh peserta didik secara heterogen berdasarkan nilai peserta didik pada mata pelajaran prakarya dan kewirausahaan. Kemudian kelompok tersebut diberi nama kelompok A, B, C, D, E. Pembentukan kelompok dilakukan oleh guru di dalam kelas. Masing-masing kelompok berdiskusi untuk mengerjakan soal - soal yang diberikan oleh guru, sedangkan guru berkeliling memantau jalannya diskusi.

Permainan (games), permainan dalam penelitian ini adalah permainan akademik. Permainan akademik dilakukan secara berkelompok oleh semua peserta didik dalam kelas. Permainan pada pertemuan pertama menggunakan paket soal. Guru menjelaskan aturan permainan. Setiap kelompok mendapatkan satu paket kartu soal yang harus dipecahkan oleh setiap kelompok. Permainan berakhir ketika semua kartu soal sudah erjawab. Peserta didik dan guru mengevaluasi permainan kelompok. Setelah selesai peserta didik dan guru membahas bersama hasil diskusi kelompok. Pertandingan (tournament), kegiatan selanjutnya adalah peserta didik melakukan tournament. Sebelum melakukan tournament, guru membagi 
peserta didik secara homogen dari rangking nilai mata pelajaran kewirausahaan sebelumnya. Peserta didik berasal dari kelompok yang berbeda dan tidak ada peserta didik dari kelompok yang sama sebelumnya. Masing-masing peserta didik dalam kelompok berlomba mengerjakan soal agar mendapatkan skor tertinggi yang nantinya akan dikumpulkan pada kelompoknya masing-masing. Guru menjelaskan penentuan pemenang tournament adalah jumlah skor yang diperoleh masing-masing peserta didik dari kelompok lama. Penghargaan kelompok (team recognition), Guru dan peserta didik menghitung perolehan skor masing-masing kelompok. Perolehan skor kelompok berasal dari jumlah skor masing-masing peserta didik dalam kelompok tersebut pada saat tournament. Pemenang tournament berdasarkan urutan perolehan skor kelompok dari yang tertinggi sampai yang terendah.

Pengamatan dilakukan oleh guru dan observer. Instrumen yang digunakan adalah lembar observasi, catatan lapangan, kartu bernomor, soal post tes dan lembar penilaian. Dari lembar observasi, pengamatan dilakukan untuk mengetahui bagaimana proses belajar mengajar, minat peserta didik mencoba berwirausaha dan keaktifan peserta didik serta menjiwai nilai-nilai kewirausahaan, sedangkan post test digunakan untuk mengetahui hasil belajar peserta didik setelah mendapatkan materi merumuskan solusi. dan masalah menggunakan model pembelajaran
TGT. Angket juga dibagikan untuk mengukur minat siswa untuk berwirausaha setelah mengikuti pembelajaran TGT yang berkesan dan menarik. Dari hasil pengamatan melalui observasi dapat diketahui bahwa Peserta didik dan guru dapat berinteraksi dengan baik, peserta didik bisa aktif yaitu peserta didik dapat berkomunikasi dengan guru dan sesama peserta didik, peserta didik mampu menjawab pertanyaan dan memecahkan masalah melalui diskusi, peserta didik dapat berbicara di depan kelas dan mengajukan pertanyaan, dengan adanya game dan tournament belajar menjadi lebih menyenangkan, peserta didik menjadi bersemangat untuk berminat dan belajar kewirausahaan untuk menjadi yang lebih baik.

Refleksi dilakukan dengan mengkaji hasil observasi serta permasalahan yang dihadapi selama tindakan berlangsung pada siklus I, diperoleh data bahwa peserta didik antusias, memiliki inspirasi berwirausaha dan memiliki semangat bekerjasama dalam mengikuti pembelajaran ini walaupun masih kurang langsung bisa faham dengan model TGT ini, karena terbiasa dengan metode ceramah yang disampaikan oleh guru tanpa media apapun. Kompetisi terlihat saat tournament, peserta didik antusias mengikuti game dan tournament. Sedangkan dari hasil angket diperoleh data bahwa mayoritas siswa menyatakan memilih opsi netral dan setuju terkait minat berwirausaha. Hasil post test menunjukkan nilai rata-rata siswa sudah tuntas, namun masih ada 
tiga siswa yang belum berhasil. Akan tetapi ada beberapa kelemahan yang dihadapi pada siklus I ini antara lain :

a) Waktu kurang di kelola dengan baik sehingga sedikit melebihi batas waktu yang ditentukan. Kemudian membuat kesepakatan dengan guru dan peserta didik untuk mengambil sedikit jam tambahan

b) Peserta didik masih bingung ketika pertama kali dijelaskan tentang permainan, dijelaskan dengan pelan dan beberapa kali bertanya peserta didik baru benar-benar paham

Setelah tahap refleksi selesai maka dilanjutkan ke siklus 2, harapannya kekurangan yang terjadi pada siklus 1 tidak terulang pada siklus selanjutnya.

2. Diskripsi Siklus Kedua

Perencanaan siklus kedua dimulai dengan guru membuka pembelajaran dengan salam dan berdoa dengan dipimpin oleh salah satu peserta didik. Guru melakukan presensi untuk mengecek kehadiran peserta didik. Kemudian kegiatan pembelajaran dilanjutkan dengan tanya jawab antara guru dan peserta didik terkait motivasi berwirausaha siswa. Kegiatan ini merupakan apersepsi yang bertujuan untuk mengetahui tingkat pemahaman dan persepsi awal peserta didik tentang materi kewirausahaan yang akan dipelajari dan menghubungkan materi yang telah dipelajari oleh peserta didik pada pertemuan selanjutnya yang dikaitkan dengan peningkatan minat berwirausaha. Untuk meminimalisir kelemahan pada pertemuan sebelumnya yaitu masih ada peserta didik yang keluar masuk dan masih ada yang mengobrol dan bermain HP maka pada pertemuan kali ini peserta didik diminta untuk mengumpulkan HP kepada guru dan akan dikembalikan ketika jam pelajaran selesai. Setelah itu guru menyiapkan media belajar berupa hand out, soal game dan paket soal tournament serta membuat instrumen penelitian berupa lembar observasi, angket, catatan lapangan, soal post test dan lembar penilaian.

Kegiatan inti pembelajaran pada pertemuan pertama adalah guru menjelaskan kepada peserta didik terkait cara memecahkan masalah. Guru melakukan tanya jawab dengan peserta didik solusi untuk memecahkan masalah. Kegiatan pembelajaran menekankan pada proses pembelajaran yang bersifat aktif. Kegiatan pembelajaran menggunakan model pembelajaran TGT menekankan pada diskusi kelompok, permainan akademik, dan turnamen. Belajar dalam kelompok (teams), Guru membagi peserta didik menjadi lima kelompok yang beranggotakan masing-masing kelompok enam atau tujuh peserta didik secara heterogen berdasarkan nilai peserta didik pada mata pelajaran kewirausahaan. Kemudian kelompok tersebut diberi nama kelompok A, B, C, D, E. Pembentukan kelompok dilakukan oleh guru. Masing-masing kelompok berdiskusi dan mengerjakan soal yang diberikan oleh guru, sedangkan guru berkeliling memantau jalannya diskusi.

Permainan (games), kegiatan dalam 
penelitian ini adalah permainan akademik. Permainan akademik dilakukan secara berkelompok oleh semua peserta didik di dalam kelas. Permainan pada pertemuan pertama menggunakan kartu. Guru menjelaskan aturan permainan bahwa setiap kelompok mendapatkan satu kartu soal yang harus dipecahkan oleh setiap kelompok. Permainan berakhir ketika semua kartu soal sudah terjawab. Peserta didik dan guru mengevaluasi permainan kelompok. Setelah selesai peserta didik dan guru membahas bersama hasil diskusi kelompok.

Pertandingan (tournament), kegiatan selanjutnya adalah peserta didik melakukan tournament. Sebelum melakukan tournament, guru membagi peserta didik secara homogen dari rangking nilai mata pelajaran prakarya dan kewirausahaan sebelumnya. Peserta didik berasal dari kelompok yang berbeda dan tidak ada peserta didik dari kelompok yang sama sebelumnya. Masing-masing peserta didik dalam kelompok berlomba mengerjakan soal agar mendapatkan skor tertinggi yang nantinya akan dikumpulkan pada kelompoknya masingmasing. Guru menjelaskan penentuan pemenang tournament adalah jumlah skor yang diperoleh masing-masing peserta didik dari kelompok lama. Penghargaan kelompok (team recognition), Guru dan peserta didik menghitung perolehan skor masing-masing kelompok. Perolehan skor kelompok berasal dari jumlah skor masing-masing peserta didik dalam kelompok tersebut pada saat tournament. Pemenang tournament berdasarkan urutan perolehan skor kelompok dari yang tertinggis ampai yang terendah.

Pengamatan dilakukan oleh guru sebagai observer. Instrumen yang digunakan adalah lembar observasi, angket. catatan lapangan, kartu bernomor, soal post test dan lembar penilaian. Dari lembar observasi, pengamatan dilakukan untuk mengetahui bagaimana proses belajar mengajar, minat berwirausaha peserta didik dan keaktifan peserta didik, sedangkan post test digunakan untuk mengetahui hasil belajar peserta didik setelah mendapatkan materi prakarya dan kewirausahaan dengan menggunakan model pembelajaran TGT. Dari hasil pengamatan melalui observasi dapat diketahui bahwa masalah yang muncul pada pertemuan sebelumnya dapat diatasi pada pertemuan kali ini dengan mengumpulkan HP ketika pembelajaran.

Refleksi dilakukan dengan mengkaji hasil observasi serta permasalahan yang dihadapi selama tindakan berlangsung pada pertemuan siklus 2 , diperoleh data bahwa jiwa minat berwirausaha peserta didik mulai tumbuh dengan ditandai oleh semangat bekerja sama dalam tim untuk serius mempelajari materi dan skor tertinggi juga sangat terlihat. Minat terlihat saat games tournament dan hasil angket, peserta didik antusias mengikuti game tournament dengan rasa ingin tahu, dan keseriusan belajar tinggi. Sudah tidak ada lagi masalah berarti yang dapat menghambat jalannya pembelajaran. Hasil post test me- 
nunjukkan peningkatan rata-rata nilai hasil pekerjaan soal siswa. Sedangkan dari hasil angket diperoleh data bahwa mayoritas siswa semakin banyak yang menyatakan memilih opsi setuju terkait minat berwirausaha.

3. Peningkatan Hasil Belajar Prakarya dan Kewirausahaan Peserta didik Menggunakan Model pembelajaran TGT

Hasil pengamatan berdasarkan lembar penilaian tentang variabel hasil belajar kewirausahaan dari siklus 1 dan 2 diperoleh data sebagai berikut:

Grafik 1. Perbandingan Hasil Belajar Siswa Siklus 1 dan 2

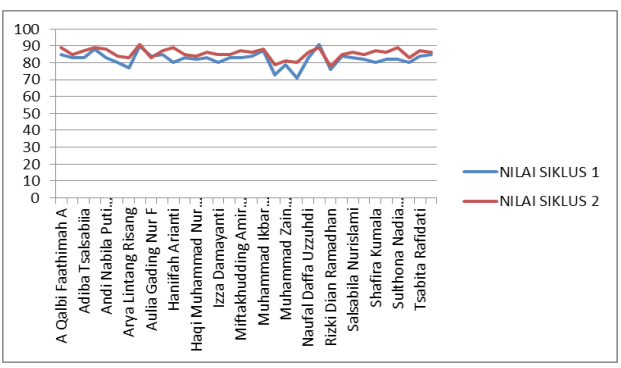

Sumber: Data Penelitian

Berdasarkan data diatas maka diketahui peningkatan hasil belajar peserta didik selain dapat dilihat dari prestasi nilai masing-masing peserta didik, juga dapat dilihat melalui peningkatan nilai rata-rata kelas. Rata-rata nilai kelas untuk siklus 1 adalah 82,30 jika dilihat rata-rata ini maka kelas tersebut telah memenuhi KKM, sedangkan rata-rata nilai siklus 2 meningkat menjadi 85,53. Pada siklus 1 ada dua peserta didik yang nilainya belum mencapai KKM sebesar 75 , sedangkan di siklus 2 seluruh peser- ta didik sudah memenuhi KKM

Peningkatan hasil belajar peserta didik dapat diketahui dari hasil pengamatan yang dilakukan saat tindakan. Pengamatan dilakukan terhadap proses belajar dan hasil belajar peserta didik. Pengamatan proses belajar mengajar dilihat berdasarkan lembar observasi, kegiatan apa saja yang dilakukan peserta didik, minat dan keaktifan peserta didik pada saat diskusi tahap team, aktif menjawab pertanyaan dan semangat berkompetisi yang sehat antar kelompok pada tahap game and tournament serta angket yang dibagikan. Kegiatan tersebut dapat dijelaskan berikut ini:

\section{a. Siklus I}

Proses belajar mengajar pembelajaran kewirausahaan pada siklus 1 adalah sebagai berikut :

1) Dalam proses belajar mengajar terdapat $100 \%$ atau 34 peserta didik yang mengikuti pelajaran. Ada 2 peserta didik yang belum tuntas.

2) Hasil belajar peserta didik

Dari TGT yang telah dilakukan pada siklus I, nilai dijelaskan dalam tabel berikut sesuai perolehan masingmasing team :

Tabel 1. Perolehan Point Kelompok TGT Siklus 1

\begin{tabular}{|c|c|c|c|}
\hline $\begin{array}{c}\text { Nama Ke- } \\
\text { lompok }\end{array}$ & $\begin{array}{c}\text { Skor game } \\
\text { kartu }\end{array}$ & $\begin{array}{c}\text { Poin tur- } \\
\text { namen }\end{array}$ & $\begin{array}{c}\text { Predikat } \\
\text { Tim }\end{array}$ \\
\hline A & 30 & 50 & \\
\hline B & 40 & 50 & Juara 3 \\
\hline C & 50 & 60 & Juara 1 \\
\hline D & 50 & 20 & \\
\hline E & 60 & 40 & Juara 2 \\
\hline
\end{tabular}

Sumber: Data Penelitian 
Berdasarkan tabel tersebut dapat dijelaskan bahwa tim yang memiliki predikat juara 1 adalah kelompok C perolehan total skor sebesar 110 yang didapat dari skor game kartu dan skor turnamen. Setelah melaksanakan tindakan refleksi pada siklus I terdapat beberapa kelemahan yang harus diperbaiki pada siklus II, diantaranya yaitu :

Waktu kurang di kelola dengan baik sehingga sedikit melebihi 90 batas waktu yang ditentukan. Pada siklus selanjutnya guru harus lebih memperhatikan waktu yang telah direncanakan, sehingga waktu bisa optimal dan tidak melebihi waktu yang disediakan. Peserta didik masih bingung ketika pertama kali dijelaskan tentang permainan, dijelaskan dengan pelan dan beberapa kali bertanya peserta didik baru benar-benar paham. Sebaiknya membuat game yang lebih mudah dimengerti oleh peserta didik, tetapi untuk siklus II peserta didik sudah paham dengan tournament karena sama dengan game siklus I sehingga untuk tournament masih sama dengan siklus I. Peserta didik masih belum optimal dalam diskusi, masih ada yang ngobrol dan kurang serius. Guru lebih mengawasi peserta didik supaya tidak mengobrol sendiri dan lebih serius.

\section{b. Siklus 2}

Proses belajar mengajar pembelajaran kewirausahaan pada siklus 2 adalah sebagai berikut :

Dalam proses belajar mengajar terdapat $100 \%$ atau 34 peserta didik mengikuti pelajaran
1) Semua peserta didik telah mencapai KKM

2) Hasil belajar peserta didik

Dari game yang telah dilakukan pada siklus 2, nilai dijelaskan dalam tabel berikut sesuai perolehan masingmasing team :

Tabel 2. Perolehan Point Kelompok TGT Siklus 2

\begin{tabular}{|c|c|c|c|}
\hline $\begin{array}{c}\text { Nama Ke- } \\
\text { lompok }\end{array}$ & $\begin{array}{c}\text { Skor game } \\
\text { kartu }\end{array}$ & $\begin{array}{c}\text { Poin tur- } \\
\text { namen }\end{array}$ & $\begin{array}{c}\text { Predikat } \\
\text { Tim }\end{array}$ \\
\hline A & 40 & 45 & Juara 3 \\
\hline B & 40 & 50 & Juara 2 \\
\hline C & 50 & 50 & Juara 1 \\
\hline D & 30 & 30 & \\
\hline E & 40 & 30 & \\
\hline
\end{tabular}

Sumber. Hasil Penelitian

Berdasarkan tabel tersebut dapat dijelaskan bahwa tim yang memiliki predikat juara 1 adalah kelompok $\mathrm{C}$ perolehan total skor sebesar 100 yang didapat dari skor game kartu dan skor turnamen

4. Peningkatan Minat Berwirausaha

Peserta Didik Menggunakan Model Pembelajaran TGT

Adapun Indikator yang digunakan untuk mengukur peningkatan minat berwirausaha peserta didik adalah dengan melihat keinginan, cita-cita dan dorongan peserta didik untuk berwirausaha. Adapun hasil observasi terhadap jiwa kompetitif peserta didik pada setiap siklusnya dapat dilihat sebagai berikut.

a. Siklus 1

Pada siklus pertama minat berwirausaha peserta didik belum terlihat 
dapat dibuktikan dengan masih banyak peserta didik yang belum berani menyampaikan pendapatnya bahwa berwirausaha khususnya usaha makanan itu mudah dan menguntungkan. Selain hal itu masih banyak peserta didik yang melakukan aktivitas lain daripada mengikuti pembelajaran dengan metode TGT. Dari hasil observasi hanya ada 3 anak yang berani menyampaikan pendapat di depan teman-temannya.

b. Siklus 2

Pada siklus 2 jiwa minat berwirausaha peserta didik sudah terlihat secara merata dan sudah lebih banyak dari siklus sebelumnya. Hasil aktivitas peserta didik menunjukkan bahwa peserta didik mampu menujukkan antusiasme belajar kewirausahaan dan menganggap sebagai sesuatu yang penting. Mereka serius berdiskusi tentang berbagai modal yang harus dipersiapkan dalam berwirausaha makanan agar bisa membuka usaha makanan dikemudian hari. Namun, terdapat pula peserta didik yang belajar giat agar menang game TGT kelompok. Saat pembelajaran, terdapat peserta didik yang memberi semangat kepada temannya yang sudah membuka usaha agar semangat berjualan. Pada saat diskusi terdapat teman yang belum paham diberi motivasi dan dijelaskan agar pada saat tournament kelompoknya dapat menjadi juara. Pada saat tournament peserta didik mengerjakan sendiri sesuai kemampuannya dan nilai dari masing-masing peserta didik dikumpulkan.
Berdasarkan hasil observasi peserta didik peserta didik senang ketika berhasil mengidentifikasi modal dalam berwirausaha makanan ditunjukkan dengan antusiasme mengikuti diskusi. Dalam observasi juga terdapat peserta didik mulai mengungkapkan ketertarikan menjual makanan kecil di sekolah karena modalnya sedikit dan keuntungan bisa untuk jajan dan mengapresiasi temannya yang sudah jualan. Hal tersebut terlihat dengan memberi tepuk tangan meriah kepada rekannya yang sudah jualan tersebut. Berdasarkan uraian hasil observasi aktivitas peserta didik selama proses pembelajaran, maka dapat disimpulkan bahwa peserta didik menunjukkan minat berwirausaha.

Melalui angket yang dibagikan, peneliti juga menemukan fakta bahwa ada peningkatan minat berwirausaha siswa dari angket yang disebar saat siklus pertama dan angket yang disebar saat siklus yang kedua walaupun peningkatannya masih belum terlalu signifikan. Hal ini karena sesuai teori yang ada, bahwa minat itu ada banyak faktor yang menentukannya. Dalam grafik berikut merupakan grafik peningkatan minat berwirausaha siswa dari hasil pengisian angket siklus 1 dan siklus 2 : 
Grafik 2. Perbandingan Minat Berwirausaha Siswa Siklus 1 dan Siklus 2

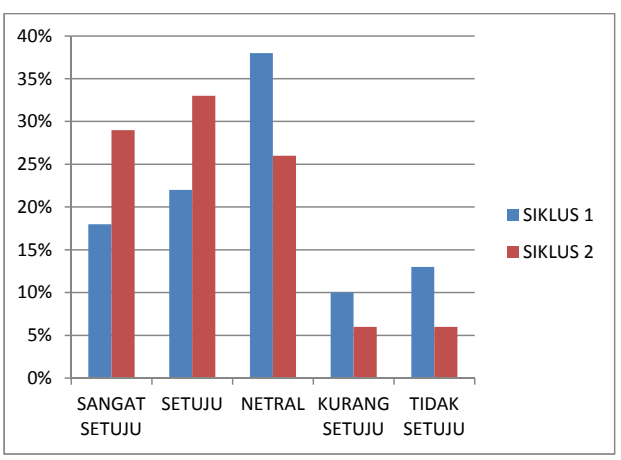

Sumber: Data Penelitian

Dari data diatas, terlihat jelas bahwa pada siklus ke 2 terjadi peningkatan jumlah prosentase siswa yang menyatakan setuju dan sangat setuju terhadap pernyataan positif tentang minat berwirausaha. Ini artinya mulai ada peningkatan minat atau ketertarikan siswa untuk berwirausaha siswa. Sebaliknya, pada pernyataan netral, kurang setuju dan tidak setuju terhadap pernyataan positif tentang minat berwirausaha terjadi penurunan prosentasi siswa yang memilih, ini artinya semakin sedikit siswa yang tidak memiliki minat berwirausaha.

\section{KESIMPULAN}

Berdasarkan penelitian dan pembahasan tentang implementasi model pembelajaran Team Game Tournament (TGT) untuk meningkatkan minat berwirausaha siswa kelas XI SMA muhammadiyah 1 Yogyakarta tahun ajaran 2017/2018, maka dapat diambil simpulan sebagai berikut:

Implementasi model pembelajaran
TGT dapat meningkatkan minat berwirausaha peserta didik dilaksanakan dengan menggunakan model penelitian tindakan Slavin Robert dengan empat tahapan yaitu: a) Perencanaan (plan) yaitu peneliti melakukan rancangan tindakan yang menjelaskan tentang apa, mengapa, kapan, dimana, oleh siapa dan bagaimana tindakan tersebut dilakukan,dan membuat instrumen, RPP dan perlengkapan lain untuk melaksanakan tindakan. b) tindakan (do) yaitu penerapan dari model pembelajaran TGT yaitu dimulai dari pembagian kelompok (Team) yang terdiri dari penjelasan peraturan permainan, pembagian peran masing-masing kelompok dan menjelaskan alur peran kelompok, selanjutnya adalah keberlangsungan game and tournament tersebut, dan yang terakhir adalah recognize team yaitu pengumuman pemenang game kompetisi yang telah selesai dilaksanakan kemudian pemberian penghargaan tim terbaik. c) Pengamatan (observing) yaitu pelaksanaan pengamatan oleh peneliti dan teman sejawat dengan menggunakan lembar observasi dan instrument lainnya. selanjutnya d) refleksi (see) yaitu mengemukakan kembali apa yang sudah terjadi. Proses pembelajaran dilaksanakan oleh guru yang dilaksanakan dengan dua siklus, masing-masing siklus satu pertemuan pada mata pelajaran prakarya dan kewirausahaan sesuai jadwal yang ada pada sekolah selama dua jam pelajaran. Peserta didik cukup antusias dan senang dalam belajar sehingga memotivasi pe- 
serta didik untuk bisa lebih bersemangat dalam pelaksanaan game dan turnamen.

Hasil belajar peserta didik setelah diimplementasikan model pembelajaran TGT dalam pembelajaran kewirausahaan adalah adanya peningkatan ratarata nilai untuk siklus 1 adalah 82,29 jika dibandingkan dengan pencapaian KKM masih sudah memenuhi, sedangkan rata-rata nilai siklus 2 mengalami peningkatan mencapai 85,52. Pada siklus 1 ada dua peserta didik yang nilainya belum mencapai KKM sebesar 75 , sedangkan di siklus 2 mengalami peningkatan jumlah peserta didik yang nilainya mencapai KKM yaitu seluruh peserta didik.

Selain pada hasil belajar, hasil penelitian ini juga menjelaskan bahwa peserta didik dapat belajar dengan aktif karena adanya interaksi antar peserta didik, guru dan peserta didik, komunikasi saat diskusi dan presentasi juga dapat menjadikan peserta didik lebih aktif dan memahamkan peserta didik tentang materi yang diajarkan oleh guru. Peserta didik juga semakin tertarik untuk belajar berwirausaha yaitu karena adanya stimulus melalui TGT yang dapat saling memotivasi untuk bersaing mendapatkan prestasi di kelas.

\section{DAFTAR PUSTAKA}

Agatha Dita Kristsada. (2010). Menumbuhkan Minat Belajar Anak. Yogyakarta: Tiara Wacana

Amir Hamzah Nasution. (2003). Enterpreneurship: from Mindset to
Strategy Edisi Keempat. Jakarta: Lembaga Penerbit Fakultas Ekonomi Universitas Indonesia

Arikunto, Suharsimi.(2008). Penelitian tindakan Kelas. Jakarta: PT. Bumi Aksara.

Budi Wahyono. (2013). "Pengaruh Pendidikan Kewirausahaan terhadap Niat Berwirausaha Siswa SMK N 1 Pedan Tahun 2013." Tesis. Universitas Sebelas Maret Surakarta.

Buchari Alma. (2004). Kewirausahaan. Bandung: Alfabeta.

Evinta Singgih. (2006). Menumbuhkan Minat Belajar Siswa. Jakarta: PT RAJA GRAFINDO PERSADA

H. Djaali. (2008). Buku Ajar Kewirausahaan-1. Jakarta: Lembaga Kajian dan Pengembangan Pendidikan

Ida Yulianti. (2013). "Pengaruh Mata Pelajaran Kewirausahaan dan Motivasi Siswa terhadap Minat Berwirausaha Siswa Kelas XI Di SMK Muhammadiyah Salaman Kabupaten Magelang". Jurnal. Universitas Muhammadiyah Purworejo

Jamal Ma'mur Asmani. (2011). Sekolah Entrepreneur. Yogyakarta: Harmoni

Kasmir. (2006). Kewirausahaan. Jakarta: PT RAJA GRAFINDO PERSADA

Maman S. (2006). Pendidikan Wiraswasta. Jakarta: Sinar Grafika Offset.

Nur dan Wikandari. 2000. Model Pembelajaran Kooperatif Tipe TGT. http://www.google.com/2017/12/ 
Model Pembelajaran Kooperatif

Tipe TGT.html (diunduh tanggal 5 Desember 2017)

Nana Sudjana dan Ahmad Rivai. (2004). Kewirausahaan Pedoman Praktis, Kiat dan Proses Menuju Sukses Edisi 3. Jakarta: Salemba Empat.

Sardiman. (2001). Menggeluti Dunia Belajar Inovatif. Yogyakarta: Gava Media

Slavin, Robert. 2008. Cooperative Learning Theory, Research and Practise. Allyn and Bacon Publisher. Boston
Sugiyono. (2012). Metode Penelitian Kuantitatif, Kualitatif, dan $R \& D$. Bandung: CV ALFABETA

Tim Penulis Naskah Kewirausahaan. (2010). Pengembangan Pendidikan Kewirausahaan. Jakarta: Kementerian Pendidikan Nasional Badan Penelitian dan Pengembangan Pusat Kurikulum.

Winkel. (2004). Pengembangan Sikap Entrepreneurship dan Intrapreneurship. Jakarta: PT INDEKS 